Hum. Hered. 1986;36:I-VII

\title{
Contents, Vol. 36, 1986
}

Managing Editor

L. Beckman, Umeå

Co-Editor

J. Lindsten, Stockholm

Editorial Board

A.C. Allison, Harrow

A.G. Beam, New York, N.Y.

K. Berg, Oslo

J.A. Book, Uppsala

L.L. Cavalli-Sforza, Stanford, Calif.

A. de la Chapelle, Helsinki

T.J. David, Manchester

F.C. Fraser, Montreal

J.A. Fraser Roberts, London

N. Freire-Maia, Curitiba

J. Frézal, Paris

R. Grubb, Lund

K. Henningsen, København

Margareta Mikkelsen, København

J. Mohr, København

A.E. Mourant, London

J.V. Neel, Ann Arbor, Mich.

U. Pettersson, Uppsala

Marianne Rasmuson, Umeå

S. Refsum, Oslo

L.D. Sanghvi, Bombay

M. Siniscalco, New York, N.Y.

F. Vogel, Heidelberg

M. Whittaker, Exeter

S. Karger $\cdot$ Medical and Scientific Publishers

Basel · München · Paris · London · New York · New Delhi · Singapore · Tokyo · Sydney Drug Dosage

The authors and the publisher have exerted every effort to ensure that drug selection and dosage set forth in this text are in accord with current recommendations and practice at the time of publication. However, in view of ongoing research, changes in government regulations, and the 
constant flow of information relating to drug therapy and drug reactions, the reader is urged to check the package insert for each drug for any change in indications and dosage and for added warnings and precautions. This is particularly important when the recommended agent is a new and/or infrequently employed drug.

All rights reserved.

No part of this publication may be translated into other languages, reproduced or utilized in any form or by any means, electronic or mechanical, including photocopying, recording,

microcopying, or by any information storage and retrieval system, without permission in writing from the publisher or, in the case of photocopying, direct payment of a specified fee to the Copyright Clearance Center (see 'Information for Readers and Subscribers').

(C) Copyright 1986 by

S. Karger AG, P.O. Box, CH- 4009 Basel (Switzerland) Printed in Switzerland by Buchdruckcrei Basler Zeitung + Basler Nachrichten AG, Basel

Contents Vol. 36,1986

No. 1 Original Paper

Incidence of Specific Anosmia in Northern Germany

Hirth, L.; Abadanian, D.; Goedde, H.W 1

Linkage Analysis of Multiple Endocrine Neoplasia, Type 2 (MEN-2) with 23 Classical

Genetic Polymorphisms

Kruger, S.D.; Gertner, J.M.; Sparkes, R.S.; Haedt, L.E.; Crist, M.; Sparkes, M.C.: Genel.

M.; Kidd, K.K 6

Relationship between African Admixture and Blood Pressure Variation in the Carribean

Hutchinson, J 12

Distribution of Alpha-1-Antitrypsin (Pi) Phenotypes in Denmark Determined by Separator

Isoelectric Focusing in Agarose Gel

Thymann, M 19

Glucose-6-phosphate Dehydrogenase Polymorphism in the Saudi Population

El-Hazmi, M.A.F.; Warsy, A.S

Genetic Markers and Malaria. Observations in Gujarat, India

Singh, I.P.; Walter, H.; Bhasin, M.K.; Bhardwaj, V.; Sudhakar, K 31

Increased Erythrocyte Adenosine Deaminase Activity without Haemolytic Anaemia

Novelli, G.; Stocchi, V.; Giannotti, A.; Magnani, M.; Dallapiccola, B 37

Human Enzyme Polymorphism on the Canary Islands. I. Gran Canaria Island Population

Martell, M.; Padrón, G.; Hernandez, M.; Afonso, J.M.; Cabrera, V.M 41

Frequency of Glucose-6-Phosphate Dehydrogenase, Pyruvate Kinase and Hexokinase Deficiency in the Saudi Population

El-Hazmi, M.A.F.; Al-Swailem, A.R.; Al-Faleh, F.Z.; Warsy, A.S 45

On the Variability of Gc Subtypes in Italy

Walter, H.; Kannapinn, G.; Dannewitz, A.; Rickards, O.; De Stefano, G.F 50

Serum Protein Polymorphisms in a Liberian Population

Willcox, M.; Beckman, G.; Beckman, L 54

Frequencies of the GPXí (or GPX'i) and CAi, Alleles in Some Congo Populations

Destro-Bisol, G.; Briziobello, A.; Adriani, A.; Spedini, G 58

Short Communication

Cytological Map of Human Y Chromosome

Verma, R.S 62 
No. 2 Review

Genetic Markers in Schizophrenia

McGuffm, P.; Sturt, E 65

Original Paper

Heterogeneity in Disease Associations

Mayo, O.; Street, D.J 89

Haptoglobin Phenotypes in Dementia of the Alzheimer Type

Matsuyama, S.S.; Cripe, A.T.; Joseph, J 93

IV

Contents

C3 Variants and Disease

Bernal, J.E.; Papiha, S.S.; Roberts, D.F 97

Genetic Variants of 6-Phosphogluconate Dehydrogenase in the Indonesian Populations

Sofro, A.S.M.; Kirk, R.L 101

Association of Red Cell Glucose-6-Phosphate Dehydrogenase with Haemoglobinopathies

Samuel, A.P.W.; Saha, N.; Acquaye, J.K.; Omer, A.; Ganeshaguru, K.; Hassounh, E. . 107

Patterns of Social and Geographical Distribution of Transferrin Subtype Polymorphism in

India

Mukherjee, B.N.; Reddy, A.P.; Malhotra, K.C.; Vijaykumar, M 113

Serum Protein Groups in Renal Cell Carcinoma

Fröhlander, N.; Ljungberg, B 119

Short Communications

Glyoxylase I Phenotypes in Some Endogamous Populations of Andhra Pradesh, India

Sampath Narasimha Char, K.; Rao, P.R 123

New Data on the Association between the Glyoxalase I and Haptoglobin Loci

Franco, M.H.L.P.; Moreira, D.M.; Salzano, F.M.; Santos, S.E.B.; Conceição, M.M.;

Schneider, $\mathrm{H} 126$

Properdin Factor B Frequencies in Four Asian Populations

Miyano, M.; Nanjo, K.; Okai, K.; Sowa, R.; Nomura, Y.; Kondo, M.; Sanke, T.; Kawa,

A.; Miyamura, K.; Aiyathurai, E.; Ferunando, R.; Vichayanrat, A 129

Glm(l) and $G \operatorname{lm}(2)$ Allotypes in Albanian Towns of Calabria

De Benedictis, G.; Rose, G.; Brancati, C; Tagarelli, A 132

Letter to the Editor 135

No. 3 Original Paper

Polymorphism of Plasminogen in Healthy Individuals and Patients with Cerebral Infarction

Nishimukai, H.; Shinmyozu, K.; Tamaki, Y 137

Biological and Environmental Sources of Variation in Plasma Lipids and Lipoproteins: The Jerusalem Lipid Research Clinic

Friedlander, Y.; Kark, J.D.; Stein, Y 143

EsD in Negro and Caucasian Populations: Is the EsD5 a 'Caucasian Allele'?

Destro-Bisol, G.; Menchicchi, F.; Ranalletta, D.; Spedini, G154

Multivariate Structure of Human Populations: Sedentary versus Migrants

Livshits, G.; Kobyliansky, E 158

Genetic Markers among Meiteis and Brahmins of Manipur, India

Singh, K.S.; Mukherjee, B.N.; Walter, H.; Lindenberg, P.; Gilbert, K.; Dannewitz, A.;

Malhotra, K.C.; Banerjee, S.; Roy, M.; Dey, B 177 
Blood Group and Height in a Multiethnic Population

Kark, J.D.; Friedlander, Y.; Stein, Y 188

Short Communications

Alpha-1-Antitrypsin Phenotypes in a Population of Jordan

Saleh, H.; Davrinche, C; Charlionet, R.; Rivat, C 192

I (C3b/C4b Inactivator) Typing by Agarose Gel Isoelectric Focusing and Immunoblotting

Technique

Nishimukai, H.; Tamaki, Y 195

Contents

$\mathrm{V}$

AcP and EsD Polymorphisms in South Sardinia

Floris Masala, R.; Gruppioni, G.; Mameli, G.E.; Porcella, P.; Vona, G

198

Erratum 200

Announcement 200

No. 4 Original Paper

Studies of HLA, Factor B (Bf), Complement C2 and C4 Haplotypes in Type 1 Diabetic and Control Families from Northern Sweden

Hägglöf, B.; Holmgren, G; Holmlund, G.; Lindblom, B.; Olaisen, B.; Teisberg, P. . . 201

Consanguinity and Congenital Heart Disease in the Rural Arab Population in Northern

Israel

Gev, D.; Roguin, N.; Freundlich, E 213

Genetic Relationships among the Inhabitants of Nine Mediterranean Countries

Triantaphyllidis, CD.; Kouvatsi, A.; Kaplanoglou, L.; Natsiou, T 218

Double Heterozygote Leftward/Rightward Deletion Type Alpha-Thalassaemia in Saudi Arabs

El-Hazmi, M.A.F.; Warsy, A.S 222

Correcting for Variable Age of Onset in the Estimation of Familial Relative Risk when

There Is a Secular Trend in Incidence of Disease

Haile, R.W.C.; Cortessis, V.K.; Perdue, S.T 227

Phosphoglucomutase-1 Subtypes: Polymorphic Occurrence of PGM1*7+ and Geographical

Variation in Japan

Yuasa, I.; Ikebuchi, J.; Suenaga, K.; Ito, K 233

Alpha-1-Antitrypsin Variation in Southern Africa

Dunn, D.S.; Madhoo, B.; Turnbull, R.; Jenkins, T 238

Linkage Analyses of Multiple Endocrine Neoplasia, Type 2A (MEN-2A) with 20 DNA

Polymorphisms: 5\% of the Genome Excluded

Kidd, K.K.; Kidd, J.R.; Castiglione, CM.; Genel, M.; Darby, J.; Cavalli-Sforza, L.L.;

Gusella, J.F 243

Serological Markers in Unipolar and Bipolar Affective Disorders

Balgir, R.S 250

Short Communications

Decrease of Transferrin C2 Frequency with Age

Beckman, L.; Beckman, G 254

Esterase D Polymorphism in Some Endogamous Populations of Andhra Pradesh

Sampath Narasimha Char, K.; Rao, P.R 256

Haptoglobin Groups and Lung Cancer 
Beckman, G.; Eklund, A.; Fröhlander, N.; Stjernberg, N 258

Polymorphism of the Seventh Complement Component, C7, in Chinese

York, L.J.; Marshall, W.H.; Huang, S.N 261

Colour Blindness Distribution in the Male Population of Rome

Malaspina, P.; Ciminelli, B.M.; Pelosi, E.; Santolamazza, P.; Modiano, G.; Santillo, C;

Lofoco, G.; Talone, C; Gatti, M.; Parisi, P 263

Pi MZ Phenotype and an Increased Prevalence of Reported Psoriasis in a Community

Survey

Home, S.L.; Junk, G.J.; Cockcroft, D.W.; Lovegrove, A.; Dosman, J.A 266

VI Contents

No. 5 Original Paper

Human MHC Class III Genes, Bf and C4, Polymorphism, Complotypes and Association

with MHC Class I Genes in the Finnish Population

Partanen, J.; Koskimies, S 269

A Study of Some Blood Genetic Characteristics of Bedouin and Non-Bedouin Arabs of

Jordan

Saha, N.; Banerjee, B 276

Phosphoglycolate Phosphatase Polymorphism: Gene Frequencies in Three Italian Samples

Santolamazza, C; Benincasa, A.; Scozzari, R281

Population Genetic Studies in the Kimberly of Western Australia

Blake, N.M.; Spargo, R.M 286

Group-Specific Component (Gc): Subtypes in the Finnish Population. Description of a

New Allele and an Apparent Mother-Child Incompatibility

Lukka, M.; Turunen, P.; Kataja, M.; Ehnholm. C 299

Factors Influencing the Frequency of Consanguineous Marriages in Japan: Marital Distance and Opportunity of Encounter

Imaizumi, Y 304

Population Genetics of Blood Group Polymorphisms in a Sample of Newborns from Melbourne, Australia

Mitchell, R.J.; Kosten, M.; Deacon. M 310

Torus Palatinus: A Segregation Analysis

Barbujani, G.; Rolo, M.; Barrai, I.; Pinto-Cisternas, J 317

A Gc Silent Allele Encountered in a Paternity Case

Suzuki, K.; Itoh, S.; Kawai, N.; Miyazaki, T.; Matsui, K.; Yamazaki, K.; Matsumoto. H. 326

Short Communications

Distribution of C3 and Bf Allotypes in Tuscany (Italy)

Domenici, R.; Giari, A.; Bargagna, M.; Weidinger, S

Acid Phosphatase Polymorphism in Some Endogamous Populations of Andhra Pradesh

Sampath Narasimha Char, K.; Lakshmi, P.; Gopalam, K.B.; Rao, P.R 333

A New BF Variant (F025)

Suzuki, K.; Matsumoto. H 336

A Silent Allele for Red Cell Acid Phosphatase in a Polish Family

Raczek, E.; Grzesik, J 339

No. 6 Original Paper

Inheritance of Human Muscle Enzyme Adaptation to Isokinetic Strength Training

Thibault, M.-C; Simoneau, J.-A.; Côté, C; Boulay, M.R., Lagassé, P.; Marcotte, M.: 
Bouchard, C 341

Variants of Glucose-6-Phosphate Dehydrogenase in a Vietnamese Population

Toncheva, D 348

The Webb (Wb) Antigen in South Wales Donors

Bloomfield, L.; Rowe, G.P.; Green, C 352

The HLA System in Italy

Olivetti, E.; Rendine, S.; Capello, N.; Curtoni, E.S.; Piazza, A 357

Gene Differentiation in Four Subcastes of Brahmins from Visakhapatnam. Andhra

Pradesh

Srikumari, C.R.; Rajanikumari, J.; Venkateswara Rao, T 373

Contents VII

Population Structure of Eastern Sicily

Beretta, M.; Mazzetti, P.; Frosina, G.; Schilirò, G.; Russo, A.; Russo, G.; Barrai, I. . 379

Investigations on the Variability of Haptoglobin, Transferrin and Gc Polymorphisms in

Assam, India

Walter, H.; Mukherjee, B.N.; Gilbert, K.; Lindenberg, P.; Dannewitz, A.; Malhotra,

K.C.; Das, B.M.; Deka, R 388

Interaction between Some Common Genotoxic Agents

Beckman, L.; Nordenson, 1397

Short Communications

Immunoglobulin Allotypes in Patients with Nasopharyngeal Carcinoma

Chaabani, H.; Ellouz, R 402

Genetic Variants of Factor B in a Population of Jordan

Saleh, H.; Davrinche, C; Charlionet, R.; Rivat, C 405

Announcements 408

Author Index 409

Subject Index 411 